\title{
Advantages and Disadvantages of the Use of Doping in the Sport of Bodybuilding
}

\author{
Hamadou Ali Djemel Abd Nacer ${ }^{1}$, Zerf Mohammed ${ }^{1}$, Mokkedes Moulay Idriss ${ }^{2}$, Atouti Nouredine ${ }^{2}$, \\ Bengoua Ali $^{2}$, Mebrouki Fatiha ${ }^{2}$
}

${ }^{1}$ Physical Education Institute Laboratory OPAPS, University of Mostaganem, Mostaganem, Algeria

${ }^{2}$ Physiology Laboratory Physical Education and Sports Institute, University of Mostaganem, Mostaganem, Algeria

\section{Email address:}

killer_forma@hotmail.fr(H. A. D. A. Nacer), biomeca.zerf@outlook.com (Z. Mohammed), mi_mokkedes@hotmail.fr(M. M. Idris), attouti2476@live.fr (A. Nouredine), bengoua67@yahoo.fr (B.Ali), mabroukifatiha@yahoo.fr(M. Fatiha)

\section{To cite this article:}

Hamadou Ali Djemel Abd Nacer, Zerf Mohammed, Mokkedes Moulay Idriss, Atouti Nouredine, Bengoua Ali, Mebrouki Fatiha. Advantages and Disadvantages of the Use of Doping in the Sport of Bodybuilding. American Journal of Sports Science. Vol. 3, No. 5, 2015, pp. 89-92.

doi: 10.11648/j.ajss.20150305.12

\begin{abstract}
The purposes of this study were to expose the dangers of doping practiced by Algerian teenager (18years) who practices bodybuilding and wants to seek results in the shortest time. From that, our subjects were five (5) Algerian teenager who practices bodybuilder for 5years ago and who volunteered accepted to involve doping as first experience in their practices. Our study based on the follow Analysis of blood, urine, and anthropometric measurements for two months where our work was divided into two team -research: Field team ${ }^{1}$ and a Lab team ${ }^{2}$. To verify the hypothesis that support: Doping gives good visual results anthropometric external in addition, it destabilizes the regulation of vital functions. From that, our aims for this study interest: (1) Are there any statistically significant differences anthropometric between the two tests of our sample? (2) Are there any statistically significant can explain destabilizes regulation of vital functions between the two tests of our sample? For that, we have chosen the analysis of T-TEST PAIRS and correlation of the volunteer involve doping practiced by our sample to compare the implementation differences anthropometric and differences of modification in the regulation of the vital functions. Based in the results accuses in two months we confirm: (1) that the Doping gives good visual results anthropometric; (2) Doping destabilizes the regulation of vital functions.
\end{abstract}

Keywords: Use of Doping, Advantages and Disadvantages, Bodybuilding

\section{Introduction}

Doping is now a global problem that follows international sporting events worldwide (David A Baron, David M Martin, and Samir Abol Magd. 2007). Historically, anti-doping efforts have focused on the detection and deterrence of doping in elite sport. There is, however, a growing concern that doping is occurring outside the elite sporting system; giving rise to the belief that the misuse of doping agents in recreational sport has become a social problem and a public health concern. The reasons for our choice of this subject is due to the death of the Algerian hero and the World Championship Mohammed Benaziza fought the Giants at the age of 33 years in the category under- $75 \mathrm{~kg}$ category. (Wikipedia, 2015) As a result, cardiovascular back, it said in the rapport that the cause come back to the doping for the Quick Preparation to the Bodybuilders Championship. Our attention for this study is due to the use of our Algerian teenager practicing this sport in the unauthorized winds of these substances by our government in addition, we can provide it from the gyms. Our set came from the reality of the gyms visits in our country that: The training weights accompanied by greater growth, due to the increase in bio-metabolism that proteins positively condense in the age of the teenager who made the perfect time to start practicing this Sports (Mohamed Mahmoud Mandalawi, 2000, p. 95). In the lack of information and program prevention in the Algerian Leisure sports. Our aims focuses on preventing, Derived from the experience of the two studies" Adolescents Training and Learning to Avoid Steroids (ATLAS; Goldberg et al., 1996, 2000) and Athletes Targeting Healthy Exercise and Nutrition Alternatives (ATHENA; Elliot et al., 2004, 2008). In order To take advantage From USA Institute of Medicine Model of Prevention. (European Union, 2014) 


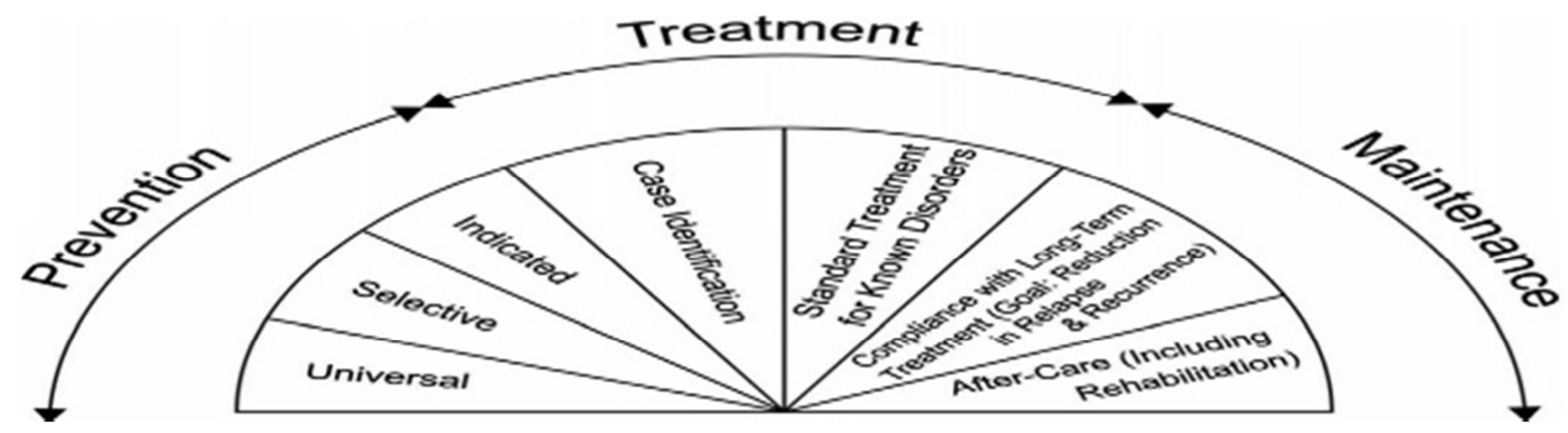

Figure 1. USA Institute of Medicine Model of Prevention (O'Connell et al., 2009).

\section{Material and Methods}

The research team role in this study is limited to monitoring the experience and take the measures planned with the agreement of the participants:

A. Medical tests(Lab team2 collection and interpretation)

- Were These tests added in the laboratory Sports Physiology of EPS Mostaganem

[1] Measuring the ratio of urea in the blood

[2] Measurement of Creatinine in the blood

[3] Measure the ratio of testosterone in the blood

[4] Blood glucose measurement

B. Anthropometric tests (Field team1 collection and interpretation, over the direction and coordination of teams)

[1] Measure Weight

[2] Measure the circumference of the shoulders

[3] Measure the chest circumference

[4] Measure the upper arm circumference

[5] Measuring thigh circumference

- From that, this study was limited to follow-up
[1] Unified training program for two months

[2] The condition of taking the medical standards

- 48 hours after the last Training session

- The medical measures taken in fasting conditions

[3] Measurement variables at the beginning of the experiment

[4] The same measurement of the variables at the end of this experiment

[5] Adjust random variables (time sleep - time program Living situation training and retrieval means).

\subsection{Data Collection}

Subjects

Our experience is composed of Five (5) voluntarily Algerian teenager who practices bodybuilder and wants to involve doping in their practice for two months where it was agreed that the Search team is not responsible for complications.

From this band the research team role is limited to monitoring the expirence and take measures planned with the agreement of the participants.

Table 1. (a (test1)-b (retest2)) Description of The Acquired Results of Our Sample in the test and retest.

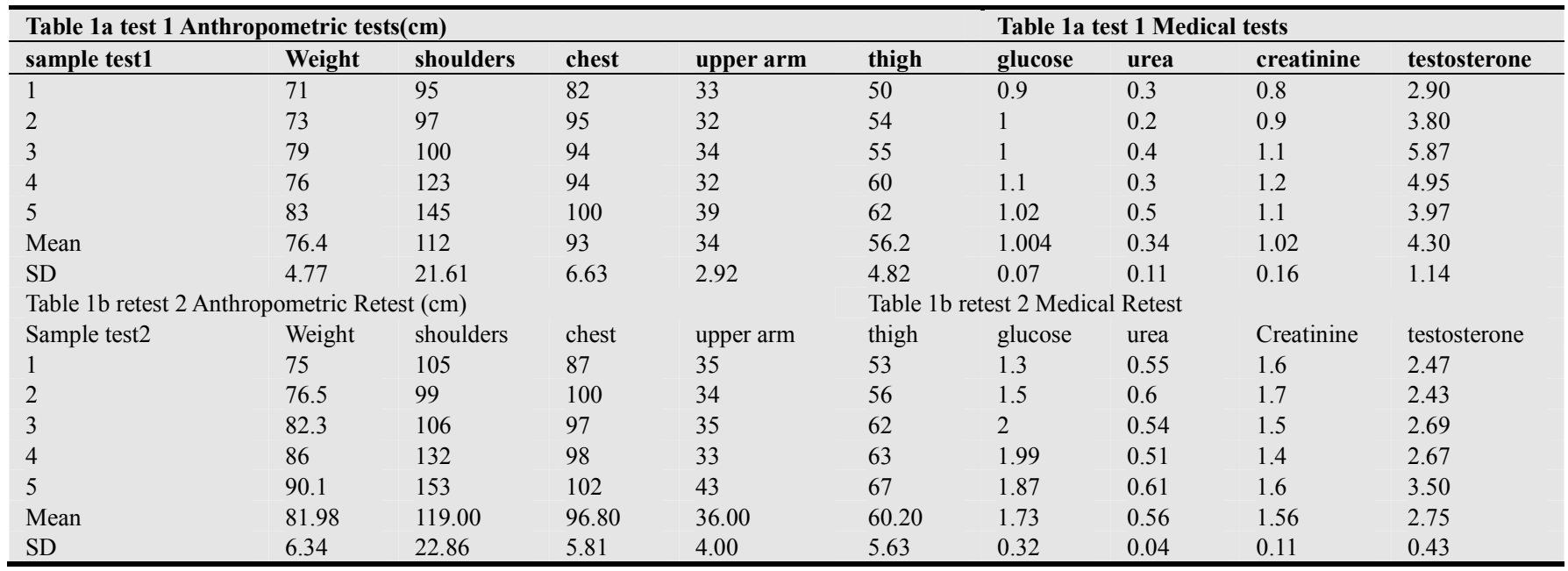

\subsection{Data Analysis}

Based on the Medical tests with their natural ratios and rates our Lab team 2 confirm that all sample in the test 1 are normalized but in the Retest test 2 all the results are Greater than the normal limit see the normal limit and fig2. 
The normal limit:

Glucose: $0.70-1.10 \mathrm{mg} / \mathrm{L}$

Urea: $0.20-0.40 \mathrm{mg} / \mathrm{L}$

Creatinine: 0.8 to $1.3 \mathrm{mg} \mathrm{mg} / \mathrm{L}$

Testosterone: $2.80-8 \mathrm{ng} / \mathrm{mL}$

Medical test1 and retest2

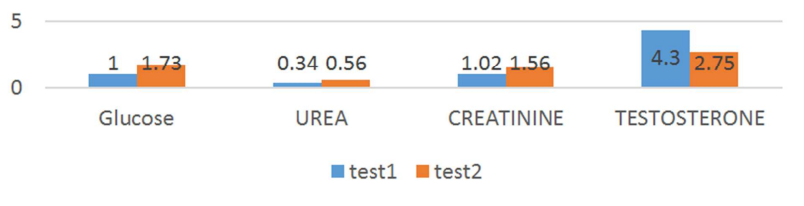

Fig. 2. Results of medical tests.

\section{Results and Discussion}

Table 2a. Shows Paired Samples Statistics calculated from Anthropometric tests $(\mathrm{cm})$.

\begin{tabular}{|c|c|c|c|c|c|c|}
\hline \multicolumn{2}{|c|}{ variable } & \multirow{2}{*}{$\begin{array}{l}\text { Mean } \\
76.4000\end{array}$} & \multirow[t]{2}{*}{$\mathbf{N}$} & \multirow{2}{*}{$\frac{\text { Std. Deviation }}{4.77493}$} & \multirow{3}{*}{$\begin{array}{l}\mathbf{t} \\
-4.288\end{array}$} & \multirow{2}{*}{ Sig. } \\
\hline \multirow{2}{*}{ Pair 1} & Weight T1 & & & & & \\
\hline & Weight T2 & 81.9800 & \multirow{9}{*}{4} & 6.34326 & & .013 \\
\hline \multirow{2}{*}{ Pair 2} & shoulders T1 & 112.0000 & & 21.61018 & \multirow{2}{*}{-4.950} & \multirow{2}{*}{.008} \\
\hline & shoulders T2 & 119.0000 & & 22.85826 & & \\
\hline \multirow{2}{*}{ Pair 3} & chest $\mathrm{T} 1$ & 93.0000 & & 6.63325 & 6517 & 003 \\
\hline & chest T2 & 96.8000 & & 5.80517 & -0.511 & .003 \\
\hline \multirow{2}{*}{ Pair 4} & $\operatorname{arm} \mathrm{T} 1$ & 34.0000 & & 2.91548 & \multirow{2}{*}{-3.651} & \multirow{2}{*}{.022} \\
\hline & $\operatorname{arm} \mathrm{T} 2$ & 36.0000 & & 4.00000 & & \\
\hline \multirow{2}{*}{ Pair 5} & thigh $\mathrm{T} 1$ & 56.2000 & & 4.81664 & \multirow{2}{*}{-4.472} & \multirow{2}{*}{.011} \\
\hline & thigh $\mathrm{T} 2$ & 60.2000 & & 5.63028 & & \\
\hline
\end{tabular}

\section{ANTHROPOMETRIC TEST1}

AND RETEST 2

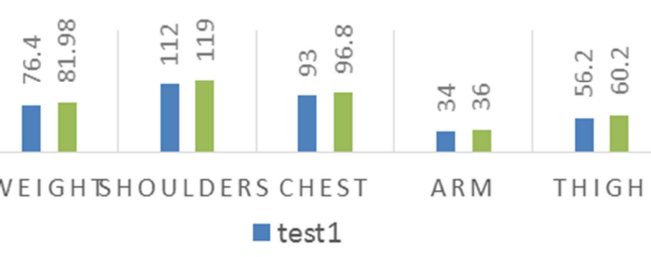

Fig 3. shows the results of Anthropometric test and retest.

Table 2b. Shows Paired Samples Correlations calculated from Anthropometric tests(cm).

\begin{tabular}{lllll}
\hline variable & & N & Correlation & Sig. \\
\hline Pair 1 & Weight \& Weight T2 & 5 & .901 & .037 \\
Pair 2 & shoulders \& shoulders T2 & 5 & .991 & .001 \\
Pair 3 & chest \& chest T2 & 5 & .987 & .002 \\
Pair 4 & arm \& arm T2 & 5 & .986 & .002 \\
Pair 5 & thigh \& thigh T2 & 5 & .938 & .018 \\
\hline
\end{tabular}

From the table 2(a-b) through the results of the paired $\mathrm{T}$ student and paired correlation of the variables of our samples, at the 0.05 level (2-tailed) and Degrees of freedom (n-1) that the $\mathrm{T}$ calculated is significant Within All comparisons. For the Paired Samples Correlations calculated is significant Within All comparisons.

\section{Conclusion}

\subsection{Conclusion 1}

Through Table 2 (a-b) and account for paired T student and paired correlation, Doping gives good visual results anthropometric external where our findings are confirmed by (Lauralee Sherwood, 2011): that Studies have confirmed that steroids can increase muscle mass when used in large amounts and coupled with heavy exercise.

Table 3a. Shows Paired Samples Statistics from the Medical tests.

\begin{tabular}{lllllll}
\hline \multicolumn{2}{l}{ variable } & Mean & N & $\begin{array}{l}\text { Std. } \\
\text { Deviation }\end{array}$ & t & $\begin{array}{l}\text { Sig. } \\
\text { (2-tailed) }\end{array}$ \\
\hline Pair & Glucose T1 & 1.0040 & .07127 & -6.212 & .003 \\
1 & Glucose T2 & 1.7320 & .31539 & & \\
Pair & Urea T1 & .3400 & .11402 & -4.359 & .012 \\
2 & Urea T2 & .5620 & 4 & .04207 & & \\
Pair & creatinine T1 & 1.02 & & 0.16 & -4.63 & .010 \\
3 & creatinine T2 & 1.56 & & 0.11 & & \\
Pair & testosteroneT1 & 4.30 & 1.14 & 2.91 & .044 \\
4 & testosteroneT2 & 2.75 & 0.43 & & & \\
\hline
\end{tabular}

Table 3b. Shows Paired Samples Correlations from the Medical tests.

\begin{tabular}{llllc}
\hline \multicolumn{2}{c}{ variable } & N & Correlation & Sig. \\
\hline Pair 1 & glucose T1\& Glucose T2 & 5 & .798 & .106 \\
Pair 2 & urea T1\& Urea T2 & 5 & .188 & .763 \\
Pair 3 & creatinine T1 \& creatinine T2 & 5 & -.747 & .147 \\
Pair 4 & testosterone T1 \& estosteroneT2 & 5 & .08 & .888 \\
\hline
\end{tabular}

From the table 3(a-b) through the results of the paired $\mathrm{T}$ student and paired correlation of the variables of our samples, at the 0.05 level (2-tailed) and Degrees of freedom (n-1) that the $\mathrm{T}$ calculated is significant Within All comparisons. For the Paired Samples Correlations calculated is not significant Within All comparisons.

\subsection{Conclusion 2}

Through Table 3 (a-b) of the paired T student and paired correlation, Doping destabilizes the regulation of vital functions and confirmation of the Lab team ${ }^{2}$ where our finding are identical to the confirming of (Lauralee Sherwood 2011): these agents adversely affect the reproductive and cardiovascular systems and the liver Kidney. Where we agree with (John Josias Conybeare (Sir.), William Neville Mann, 1975)that the simplest test of renal function is the measurement of the blood urea level. The normal range is from 20 to $40 \mathrm{mg}$. per $100 \mathrm{ml}$. The actual level depends upon the equilibrium between urea productions from protein.

For the creatinine, we agree with (CATHEY PINCKEY AND EDWARD R. PINCKNEY, M.D., 1982): that the Normal values: Blood serum creatinine values range for 0.8 to $1.3 \mathrm{mg}$ per $100-\mathrm{ml}$.

From the measured of testosterone we agreed with (David Wild, 2013) for that the Normal values Testosterone are $0.22-2.9 \mathrm{nmol} / \mathrm{L}$ 9.9-27.8nmol/L for Women 0.06-0.82 $\mathrm{ng} / \mathrm{mL}$ and Men 2.8-8.0 ng/mL (Bayer ACS:Centaur). 
For the measured of Glucose, we agreed with (G. P. TALWAR,L .M. SRIVASTAVA, 2006) blood sugar concentration are from $70 \mathrm{mg} / 100 \mathrm{ml}$ to $120 \mathrm{mg}$ of glucose in blood.

\section{Discussion and Conclusion of our experience}

Through Table 3 (a-b) from our experience, we find that doping destabilizes the regulation of vital functions. from that we consider the practice of doping can only be possible with medical care, but the death of the great athletes doping Gide us explain them as medical mistakes. For this reason, we recommending our athletes to avoid these practices because the health requires a good reflection of the actors and decision makers (Yves Géry, 2012). Where our find Background theorical based on the site by (Steven B. Karch, MD, FFFLM, 2006)that the hypothesis of doping is easily advanced to the athletes who use it for quick visual successful results in our case this result is significant in the anthropometric variables. Our teenagers must avoid this ideal because their health could be in danger, from that we recommend our leaders in sports to create programs of prevention in the Algerian Leisure sports. Our aims focuses on preventing, Derived from the experience of the USA Institute of Medicine Model of Prevention and formed Anti-doping policy for the education of our athlete (Ivan Waddington,Andy Smit, 2009).

Our results and recommendation

1 - Doping gives good visual results anthropometric.

2- Doping destabilizes the regulation of vital functions.

3- Formed Anti-doping policy for the education of our athlete as Program of prevention in the Algerian Leisure and athletics sports.

Our aim

For our sample and responsible in sports health in our country:

- Health foremost.

- Integrated the Anti-doping policy for the education of our athlete.
- Study the problem posed in other similar studies.

- Take advantage of this study in the assessment Program of the Algerians prevention.

\section{References}

[1] CATHEY PINCKEY AND EDWARD R. PINCKNEY, M.D. (1982). MEDICAL TESTS.

[2] DAVID A BARON, DAVID M MARTIN, and SAMIR ABOL MAGD. (2007). Doping in sports and its spread to at-risk populations: an international review. World Psychiatry, 6(2), 118-123. doi:PMC2219897

[3] David Wild. (2013). The Immunoassay Handbook Theory and applications of ligand binding, ELISA and related techniques. (4. Edition, Ed.) Access Online via Elsevier.

[4] European Union. (2014). Study on Doping Prevention. Luxembourg: Publications Office of the European Union.

[5] G. P. TALWAR,L. M. SRIVASTAVA. (2006). TEXTBOOK OF BIOCHEMISTRY AND HUMAN BIOLOGY. new Dalhi: PHI Learning Pvt. Ltd.

[6] Ivan Waddington,Andy Smit. (2009). An Introduction to Drugs in Sport: Addicted to Winning? USA: Routledge.

[7] John Josias Conybeare (Sir.), William Neville Mann. (1975). Conybeare's Textbook of Medicine. C. Livingstone: Amazon France.

[8] Lauralee Sherwood. (2011). Fundamentals of Human Physiology. USA: CengageBrain.com.

[9] Steven B. Karch, MD, FFFLM. (2006). Drug Abuse Handbook. USA: CRC Press.

[10] Wikipedia. (2015, 08 01). Mohamed Benaziza. Retrieved from Portail de la musculation: fr.wikipedia.org/wiki/Mohamed_Benaziza

[11] Yves Géry. (2012). La Santé de l'homme : 1942-2012 - 70 ans d'éducation pour la santé. 420. 